\title{
What Role for the Commission and the ECB in the European Stability Mechanism?
}

\author{
Anastasia Karatzia and Menelaos Markakis*
}

\begin{abstract}
This article examines the transformation of the role of the European Commission and the European Central Bank (ECB) in the context of the Economic and Monetary Union (EMU), from institutions acting within the EU institutional framework, to actors taking on new tasks in the realm of international law as part of the structure of the European Stability Mechanism (ESM). It expounds the legal framework applying to the two institutions in the ESM by analysing the currently applicable legislation as well as recent case law of the Court of Justice of the European Union (CJEU) (Ledra and Mallis). It argues that the applicable legal framework remains underdeveloped and unclear, especially with regard to the obligations incumbent on the ECB in the ESM, which have not yet been examined by the EU courts. Exploring the main challenges resulting from the ambiguity of the tasks and obligations conferred on the two EU institutions in the ESM, the article argues that all EU law applies in principle to the activities of the EU institutions in the ESM. It then shifts the focus to political and legal accountability, the emphasis being on direct and indirect actions before the CJEU, including the vexed issue of liability of the EU institutions for damages caused by their actions in the ESM. The article concludes with a forward-looking assessment in light of the Five Presidents' Report on Completing the EMU, which stipulates that the governance of the ESM should be integrated within the framework of EU law. The article questions whether a future incorporation of the ESM's governance in EU law could address any of the challenges resulting from the current uncertainty about the role and potential liability of the Commission and the ECB for their actions in the ESM, and makes a number of recommendations as to how the ESM should be incorporated into EU law.
\end{abstract}

Keywords: European Stability Mechanism; Economic and Monetary Union; Financial Assistance; European Central Bank; Liability

\section{Introduction}

The European Stability Mechanism (ESM), which is the permanent mechanism for giving financial assistance to Eurozone Member States, has been in existence for more than four years. Although it is an intergovernmental organisation established under international law, the ESM has 'borrowed' the European Commission and the European Central Bank (ECB) 
from the EU legal order. Both these EU institutions play a central role in the operation of the ESM, notably in the negotiations for financial assistance packages. However, their exact tasks, duties and obligations remain rather cryptic. What is more, the legitimacy of their involvement in the ESM is uncertain despite the green light given by the Court of Justice of the European Union (CJEU) to the establishment of the ESM in Pringle. ${ }^{1}$

This contribution examines the transformation of the role of the Commission and the ECB in the context of the Economic and Monetary Union (EMU), from institutions acting within the EU institutional framework, to actors taking on new tasks in the realm of international law as part of the ESM's institutional structure. It presents an account of the current legal framework applying to the two institutions in the ESM, taking into consideration both the applicable legislation (i.e. EU law and the ESM Treaty) and recent case law of the CJEU. It argues that the current body of law governing the actions of the two institutions in the ESM is neither fully developed, nor clear, despite the recent clarifications by the CJEU in the cases of Mallis and Ledra. ${ }^{2}$ The article deals with the main challenges resulting from the ambiguity of the tasks and obligations conferred on the two institutions in the ESM and explores whether a future incorporation of the ESM's governance in the EU Treaty, as stipulated in the 2015 Five Presidents' Report, ${ }^{3}$ could address these challenges.

The article is divided in three parts. Firstly, it gives an overview of the legal framework governing the activities of the two EU institutions in the ESM. It analyses the applicable legislation and the lessons learnt from recent CJEU judgments concerning the duties of the two EU institutions when acting in the ESM. It argues that the CJEU in Ledra made a much broader point about the applicability of EU law to the actions of the Commission and the ECB than simply declaring that the two institutions are bound by the Charter when acting outside EU law. A host of questions arise as a result of the CJEU's approach, including whether all EU law should govern the actions of the EU institutions

\footnotetext{
* Assistant Professor in EU Law, Erasmus University Rotterdam; and Postdoctoral Researcher, European Research Centre for Economic and Financial Governance, Erasmus University Rotterdam respectively. We would like to thank the anonymous reviewers, the participants of the conference held at Cambridge in March 2017, Professor Fabian Amtenbrink, Dr. René Repasi, and our colleagues at the Department of International and EU Law, Erasmus School of Law for their valuable feedback. The usual disclaimer applies.

${ }^{1}$ For a critique see P Craig 'Pringle and the Use of EU Institutions Outside the EU Legal Framework: Foundations, Procedure and Substance' (2013) 9 EuConst 263.

2 Joined Cases C-105/15 $\mathrm{P}$ to C-109/15 $\mathrm{P}$ Mallis and Malli v Commission and ECB [2016] ECLI:EU:C:2016:702; Joined Cases C-8/15 P to C-10/15 P Ledra Advertising Ltd $v$ Commission and ECB [2016] ECLI:EU:C:2016:701.

${ }^{3}$ J-C Juncker and others, 'The Five Presidents' Report: Completing Europe's Economic and Monetary Union' (22 June 2015) <ec.europa.eu/commission/publications/five-presidents-report-completing-europes-economicand-monetary-union_en > accessed 6 May 2017.
} 
within the framework of the ESM, and what the confines of the duties of the two institutions are. The second part of this contribution attempts to tackle these questions and argues that it is easier to identify the tasks conferred on the Commission in the context of the ESM than those incumbent on the ECB. Moreover, it is argued that, even assuming that the full scope of EU law applies in principle to the two EU institutions when acting under the ESM, further questions are raised concerning judicial protection and the availability of avenues to challenge the actions of the Commission and the ECB. Finally, the article engages in a forward-looking assessment of possible changes to the governance of the ESM if and when it is incorporated into EU law. More specifically, it assesses the implications of a future incorporation of the ESM into the EU legal framework, which was suggested in the Five Presidents' Report. The said Report is light on details as it does not specify the way(s) in which the ESM can or should be brought under the full scope of EU law. The third part of this contribution examines the intricacies of this future scenario and inquires whether the implementation of this proposal would address any of the challenges resulting from the current uncertainty about the role and potential liability of the Commission and the ECB for their actions in the ESM.

\section{Mapping the legal framework}

In its four years of existence, the ESM has provided financial support of EUR 9 billion to Cyprus in 2013 in addition to EUR 1 billion made available to the country by the International Monetary Fund (IMF), and up to EUR 86 billion to Greece in 2015 as part of the third economic adjustment programme for the country. ${ }^{4}$

Established as an intergovernmental organisation governed by public international law, the ESM was given a host of instruments including the ability to grant precautionary financial assistance, financial assistance for the re-capitalisation of financial institutions of an ESM Member, ${ }^{5}$ and the power to resort to primary market bond purchases as part of an overall financial assistance programme strategy. ${ }^{6}$ Most notably, Article 16(1) of the ESM Treaty (ESMT) stipulates that the ESM may grant financial assistance 'in the form of a loan to an ESM Member', while Article 12(1) ESMT, which is the basis for such support, refers to

\footnotetext{
${ }_{5}^{4}$ For details see the ESM website: <www.esm.europa.eu/> accessed 8 May 2017.

5 See the financial assistance for the recapitalisation of the Spanish banking sector: <www.esm.europa.eu/assistance/spain\#programme_timeline_for_spain> accessed 8 May 2017.

${ }^{6}$ See arts 14-18 ESMT.
} 
the 'strict conditionality' that must be attached to any grant of financial aid. ${ }^{7}$

\subsection{The role of the two institutions according to the ESM Treaty and By- Laws}

The Commission and the ECB do not constitute part of the ESM's governance structure per se, since ESM decisions can only be adopted by the Board of Governors or the Board of Directors. The ESMT (Article 5(f)) specifically states that the Board of Governors, which consists of the finance ministers of the Eurozone Member States, takes the decision to provide stability support, 'including the economic policy conditionality as stated in the memorandum of understanding (...)', and the terms of this conditionality. ${ }^{8}$ The Board of Directors consists of 'people of high competence in economic and financial matters' from each Member State, who are appointed by each Governor (Article 6(1)) and have the authority to 'call in authorised unpaid capital' (Article 9(2)) and take decisions inter alia as delegated by the Board of Governors. ${ }^{9}$ From an organisational perspective, members of the European Commission and the President of the ECB may observe the meetings of the Board of Governors (Article 5(3)) and of the Board of Directors (Article 6(2)).

Even though -formally speaking- the Commission and the ECB are not part of the ESM's governance structure, their role in the context of financial assistance packages is not at all negligible. According to Articles 5(6)(g) and 13(3) ESMT, the Board of Directors gives a mandate to the Commission to undertake certain tasks, including an assessment of the existence of risk to the financial stability of the euro area, an assessment of the sustainability of public debt, an assessment of the financing needs of the troubled ESM Member State, and -crucially - the negotiation of the economic policy conditionality attached to a financial assistance package. The Commission undertakes these tasks in liaison with the ECB, and finally signs the Memorandum of Understanding (MoU) on behalf of the ESM after approval by the Board of Governors (Article 13(3) and (4) ESMT). When the Commission and the ECB find that a failure to grant financial assistance would threaten the economic and

\footnotetext{
${ }^{7}$ For a detailed discussion on conditionality see M Ioannidis, 'EU Financial Assistance Conditionality after "Two Pack" (2014) <ssrn.com/abstract=2398914> accessed 6 May 2017.

${ }^{8}$ It should be noted here that the members of the Board of Governors are the same persons as those sitting in the Eurogroup.

${ }^{9}$ See also the ESM By-Laws (8 December 2014) <www.esm.europa.eu/sites/default/files/esm_by-laws.pdf> accessed 2 May 2017.
} 
financial stability of the euro area, they have the task of 'promptly' advising the Chairperson and the Managing Director accordingly, and requesting the 'application of the emergency voting procedure' (Article 4(4)). ${ }^{10}$ An assessment by the Commission and the ECB is also the basis on which the Board of Directors may decide whether any additional form of financial assistance is needed (Article 14(6)).

With regard to tasks that belong to the Commission, Article 13(7) ESMT entrusts the Commission -in liaison with the ECB and, whenever possible, together with the IMF- with monitoring compliance with the conditionality attached to the financial assistance programmes. The Commission is responsible for reporting on the payment of the tranches of financial assistance to the recipient Member State, and its reports are the basis for decisions by the Board of Directors concerning the recapitalisation of financial institutions of ESM Member States (Article 15(5)), ESM loans (Article 16(5)), and primary market facilities (Article 17(5)).

In addition to working with the Commission and the IMF for tasks previously mentioned, the ECB is responsible for undertaking an analysis in order to recognise the existence of 'exceptional financial market circumstances and risks to financial stability' which could constitute the basis for decisions on interventions on the secondary market (Article 18(2)).

The ESMT does not provide any further details about the respective roles of the Commission and the ECB or about the way in which the two institutions are to fulfil their tasks. Furthermore, to the best of our knowledge, there are no other publicly accessible documents or guidelines on the positions of the two institutions in previous bailout negotiations either. This lack of information as to the specifics of the role of the two institutions can be seen in light of the already identified lack of transparency in the ESM. ${ }^{11}$ Article 34 ESMT imposes a broad obligation of confidentiality, prohibiting not only those who work or have worked for the ESM, but also anyone who works or has worked in

\footnotetext{
10 Ibid art 8(1); see also ESM General Terms for ESM Financial Assistance Facility Agreements <www.esm.europa.eu/legal-documents?field_documents_category_tid[]=273\#legal-preselect> accessed 5 May 2017.

${ }^{11}$ MP Maduro, 'A New Governance for the European Union and the Euro: Democracy and Justice' [2012] Robert Schuman Centre for Advanced Studies Policy Paper No 11. Generally speaking, from 2012-2016 the ESM issued a number of soft laws such as codes, guidelines, and lending documentation in an attempt to provide further details as to its operation and to enhance the openness of its governance and decision-making processes. This attempt received a mixed reaction from the academic literature, with some authors characterising it as 'modest in substance': see L Daniele and others, Democracy in the EMU in the Aftermath of the Crisis (Springer, Cham 2017) 207-08; M De Nes, 'The ESM and the Principle of Transparency' (2015) 7 Perspectives on Federalism 128, and the literature cited therein.
} 
connection with the ESM from disclosing information that is subject to professional secrecy. This confidentiality obligation applies even after the duties of the persons concerned have ceased. The ESMT does not define the term 'professional secrecy' and does not stipulate which type of information is subject to it. ${ }^{12}$ It is also impossible to request access to the documents of the Board of Governors, the Board of Directors, the Managing Director, and 'other staff members': according to Article 35 ESMT, these actors 'enjoy inviolability in respect of their official papers and documents.' One could doubt whether the members of the Commission and the ECB should be considered 'staff members' of the ESM and thus whether Article 35 would apply to them. Even so, Article 32(5) ESMT specifies that, in any case, ' $[\mathrm{t}]$ he archives of the ESM and all documents belonging to the ESM or held by it, shall be inviolable.'

Aside from the ESMT, the most detailed provisions relating to the role of the Commission and the ECB in the ESM are those included in Article 17 of the ESM By-Laws, which specifies the conditions for the communication and disclosure of documents relating to ESM in situations other than internal ones. According to this provision, documents drawn up by or on behalf of the Commission or the ECB for use by the ESM 'may be communicated or otherwise disclosed only in accordance with the rules governing disclosure of the documents of the relevant institution.' At first sight, Article 17(2) indicates that the Commission and the $\mathrm{ECB}^{13}$ are bound by the EU rules on access to documents. These could potentially include the full scope of transparency obligations normally applying to the EU institutions within the scope of EU law, such as Regulation 1049/2001 ${ }^{14}$ and the separate Rules of Procedure of the ECB. ${ }^{15}$

Assuming that the above reading of the ESMT is correct, it should also be noted that the transparency obligations of the two institutions in the ESM would not only be defined by the applicable legal framework, but would also be limited according to it. For instance, under Regulation 1049/2001, EU institutions can refuse access to their documents on grounds of public interest and the privacy and integrity of the individual. ${ }^{16}$ Moreover, when talking about the transparency of the two institutions, one should be cautious not to put the Commission on

\footnotetext{
${ }^{12}$ K Tuori and K Tuori, The Eurozone Crisis: A Constitutional Analysis (CUP, Cambridge 2014) 218.

${ }^{13}$ Art 17(2) also refers to the IMF.

${ }^{14}$ Regulation (EC) 1049/2001 of the European Parliament and of the Council of 30 May 2001 regarding public access to European Parliament, Council and Commission documents [2001] OJ L145/43.

15 Decision of the European Central Bank of 4 March 2004 on public access to European Central Bank documents (ECB/2004/3) [2004] OJ L80/42, as currently in force.

${ }^{16}$ See art 4 of Regulation 1049/2001 on the exception on the right of access to documents.
} 
a par with the ECB. Under EU law, rules governing transparency are largely contextual, resulting in diverse transparency obligations across EU institutions, bodies, and agencies. ${ }^{17}$ Not only that, but the ECB, in particular, differs from the Commission, the European Parliament, and the Council, in so far as it is subject to the Treaty obligation to provide access to documents only when exercising its 'administrative tasks' (Article 15(3) TFEU). Although there is no precise definition of what is included in the category of administrative tasks, it is generally acknowledged that EU law favours a wider access to documents from EU institutions acting in their legislative capacity than in their administrative capacity. ${ }^{18}$ It can be said with certainty that the two institutions are not acting in any legislative capacity in the ESM, which already points out to a potentially limited scope for transparency.

However, Article 17(3) of the ESM By-Laws stipulates that certain documents are subject to a different framework of openness than the one described above. Essentially, these include the most salient documents produced by the Commission and the ECB for use by the ESM: their conclusions on the existence of an imminent threat to the economic and financial sustainability of the euro area that would trigger an emergency voting procedure (Article 4(4) ESMT); their assessment of a Member State's request for stability support (Article 13(1) ESMT); the MoUs (Article 13(3) ESMT); documents related to the monitoring of a Member State's compliance with the MoU conditionality (Article 13(7) ESMT); and ECB decisions on interventions on the secondary market (Article 18(2) ESMT). These documents can be disclosed to parties other than the ESM Members, the Commission, the ECB, and the IMF, only after authorisation by the ESM Managing Director. ${ }^{19}$

The ESM Transparency Initiative, which was endorsed by the ESM's Board of Governors on 16 June 2016, is a welcome development in opening up the details of the role of the two institutions: $:^{20}$

Specifically, the ESM now discloses on its website all programme-related documents such as the pre-meeting annotated agendas of the BoG and BoD, key draft and/or final programme documents ("such as draft Memoranda of Understanding, draft financial facility agreements, the assessments by the

\footnotetext{
${ }^{17}$ A Alemanno, 'Unpacking the Principle of Openness in EU Law: Transparency, Participation and Democracy' (2014) 39 ELRev 72.

${ }^{18}$ D Curtin and P Leino-Sandberg 'Openness, Transparency, and the Right of Access to Documents in the EU' [2016] Study for the European Parliament DG for International Policies.

${ }^{19}$ Art 17(5) ESM By-Laws.

${ }^{20}$ European Stability Mechanism, 'Summary of Decisions: Board of Governors' Annual Meeting 16 June 2016 Luxembourg (16 June 2016) <www.esm.europa.eu/sites/default/files/documents/2016_06_16_bog_am2016_summary_of_decisions.pdf> accessed 8 May 2017.
} 
Troika/Quadriga on risks to financial stability, debt sustainability analyses and financing needs, ahead of Board of Governors and Board of Directors meetings"), summaries of $\mathrm{BoG}$ and $\mathrm{BoD}$ decisions and approved programmerelated documents. ${ }^{21}$

There are, however, notable omissions as well as exceptions from disclosure according to the ESM By-Laws. In its recent report on the ESM, Transparency International EU (TI EU) argues that the ESM should establish a procedure allowing the public to petition the ESM for access to documents drawn up by the ESM, as well as create a public register of documents. ${ }^{22}$ TI EU further recommends that the ESM clarify in its By-Laws what constitutes an 'overriding public interest' as a basis for precluding the disclosure of ESM documents. ${ }^{23}$ Moreover, it argues that the ESM should make available to the public, economic models and underlying assumptions that it uses, including those used to compute debt sustainability; and redacted minutes of the meetings of the Board of Directors and Board of Governors. ${ }^{24}$

In spite of the (partial) opening up of the operations of the ESM to the public eye, there is still some uncertainty surrounding the actual tasks of the Commission and the ECB in the ESM. As seen above, the most detailed legal provisions about the obligations of the Commission and the ECB in the ESM have to do with what the two institutions cannot disclose to the public. The implications of such uncertainty are discussed later in this article. For now, we will move on to see how the CJEU has helped delineate the role of the two institutions in the ESM, on two different occasions: in the case of Pringle, and in direct actions brought by individuals contesting the terms of MoUs signed between the ESM and an ESM Member State.

\subsection{The seal of approval by the CJEU}

Despite the uncertainty surrounding the actual tasks of the two institutions in the ESM, the CJEU found that the use of the two institutions by the ESM was in line with EU law. To refresh the memory of the reader, in the case of Pringle the Court dismissed the challenge to the conferral of powers upon the EU institutions pursuant to the ESMT. ${ }^{25}$ The Court relied on

\footnotetext{
${ }^{21}$ Transparency International EU, 'From Crisis to Stability: How to Make the European Stability Mechanism Transparent and Accountable' (2017) <transparency.eu/wpcontent/uploads/2017/03/ESM_Report_DIGITALversion.pdf> accessed 6 May 2017, 30 .

${ }^{22}$ Ibid 9.

23 Ibid.

24 Ibid.

${ }^{25}$ Case C-370/12 Pringle v Government of Ireland, Ireland and the Attorney General [2012] ECR I-756.
} 
prior case $\operatorname{law}^{26}$ to rule that Member States can entrust tasks to the EU institutions outside the framework of the EU as long as such tasks 'do not alter the essential character of the powers conferred on those institutions' by the TEU and TFEU. ${ }^{27}$

The Court concluded that the tasks conferred on the Commission and the ECB did not give any powers to the two institutions 'to make decisions on their own', and that their decisions 'solely commit[ted] the ESM' ${ }^{28}$ The starting point of the Court's argument was that the Commission is obliged under article 17(1) TEU 'to promote the general interest of the Union' and 'oversee the application of Union law'. The objective of the ESMT was to ensure the financial stability of the euro area as a whole, hence promoting the general interest of the Union. Therefore, so the argument goes, the task of the Commission under the ESMT to ensure that the financial assistance programmes were consistent with EU law was part of the Commission's role to oversee the application of EU law. ${ }^{29}$ A similar line of thought was applied to the ECB, starting from Article 282(2) TFEU according to which the ECB can act in support of the EU's general economic policies.

Yet the Court's judgment in Pringle has not entirely legitimised the use of EU institutions under the ESM. Problematic issues remained both with regard to the legitimacy of allowing the two institutions to act (i.e. the core of the matter), and the procedural legal requirements on the exact powers of the Commission and the ECB when acting in the ESM viz. any limitations to their discretion to act, or any obligations to interact with other EU institutions in the process (that is, the details). ${ }^{30}$ With regard to the former, academics have voiced criticisms over the arguably misplaced parallelism of the use of EU institutions in the ESM and their use in the context of international agreements made by the EU: contrary to the ESM, the international agreements had their legal basis in the Treaty (Article 218 TFEU), meaning that their adoption was in line with the EU decision-making framework. ${ }^{31}$ Moreover, it was argued that bestowing a role to two EU institutions outside the scope of EU law

\footnotetext{
${ }^{26}$ Joined Cases C-181/91 and C-248/91 Parliament v Council and Commission [1993] ECR I-3685; Case C316/91 Parliament $v$ Council [1994] ECR I-625.

${ }^{27}$ Case C-370/12 Pringle, paras 158-65.

${ }^{28}$ Ibid para 161.

${ }^{29}$ Ibid paras 163-64.

${ }^{30}$ Craig (n 1) 271; G Lo Schiavo, 'The Judicial 'Bail Out' of the European Stability Mechanism: Comment on the Pringle Case' (2013) EUI Research Paper in Law 09/2013, 19.

${ }^{31}$ For example, Opinion 1/92 Draft agreement between the Community, on the one hand, and the countries of the European Free Trade Association, on the other, relating to the creation of the European Economic Area [1992] ECR I-3493 para 20; Craig (n 1) 277; for a critical look on the ESM more generally see J Tomkin, 'Contradiction, Circumvention and Conceptual Gymnastics: The Impact of the Adoption of the ESM Treaty on the State of European Democracy' (2013) 14 German Law Journal 169.
} 
without the involvement of the European Parliament and the Council in the decision-making process contradicted the principle of EU institutional balance which in principle legitimises the decisions taken at the EU level by ensuring the representation of diverse interests. ${ }^{32}$

Nonetheless, there is a difference between ruling on whether an EU institution can act as part of an intergovernmental organisation, and specifying the details of how the said institution is to act. With regard to the latter, Pringle adds little to the picture. In this respect, it has been argued that the judgment allows such a wide margin of discretion to groups of Member States 'to establish through intergovernmental agreements institutional structures which lie outside the Union framework but which still involve Union institutions', that it can be characterised as a type of 'constitutional mutation." 33

To an extent, the silence of the CJEU in Pringle could be attributed to the nature of the claim at hand. The case originated from a preliminary reference request from the Irish Supreme Court. It was contesting the validity of the establishment of the ESM but it was not contesting the actions of the Commission and the ECB in a specific situation such as, for example, their actions in the negotiations for a particular financial assistance package agreed between the ESM and a financially troubled Member State. As such, the Court did not discuss further the responsibilities of the two institutions and did not clarify whether the Charter applied to them. More recent litigation from the CJEU has shed some light on the role of the two EU institutions when acting under the ESM.

\subsection{Unpacking the duties of the EU institutions}

The cases of Mallis and Ledra have given the opportunity to the Court to delve further into the substance of the institutions' involvement in the ESM. Put together, the judgments in both cases advance our understanding in the field but, as will be seen later on, they do not answer all our questions. The details of the cases, as well as their progression from the General Court to the ECJ, are well documented elsewhere and thus will not be repeated here. ${ }^{34}$ Suffice it to say that the cases concern the 2013 MoU signed between Cyprus and the ESM for the provision of financial assistance to the country as well as the 'haircut' imposed on bank

\footnotetext{
${ }^{32}$ M Dawson and F de Witte, 'Constitutional Balance in the EU After the Euro-crisis' (2013) 76 MLR 817.

${ }^{33}$ Tuori and Tuori (n 12) 162.

${ }^{34}$ A Karatzia, 'An Overview of Litigation in the Context of Financial Assistance to Eurozone Member States' in M Szabó and others (eds), Hungarian Yearbook of International and European Law 2016 (Eleven Publishing, The Hague 2017) ch 34; S Laulé Shaelou and A Karatzia, 'Some Preliminary Thoughts on the Cyprus Bail-In Litigation: A Commentary on Mallis and Ledra' (2018) 43 ELRev (forthcoming); A Poulou, 'The Liability of the EU in the ESM Framework' (2017) 24 Maastricht Journal of European and Comparative Law 127.
} 
depositors for the purposes of recapitalising the Cypriot banks. ${ }^{35}$

To a large extent, the two cases confirm and build on the CJEU judgment in Pringle; indeed, references to Pringle are plentiful. Based on the two cases, we can make five observations about the role of the two institutions in the ESM. ${ }^{36}$

First, the Commission and the ECB are acting as different bodies than the Eurogroup in the ESM. The Commission and the ECB are neither delegating powers to the Eurogroup, nor are they controlling the Eurogroup, despite their participation in Eurogroup meetings according to Protocol 14 on the Eurogroup. ${ }^{37}$ This is, perhaps, a self-evident point, yet the Court clarified it because the applicants in Mallis had argued that the decision for the haircut on deposits, which was included in a statement of the Eurogroup, was actually taken by the Commission and the ECB. Yet it is noteworthy that in its ruling the CJEU did not undertake an examination of what the Commission and the ECB do when they sit in Eurogroup meetings. This brings to the spotlight once more the overall lack of transparency in the whole structure of the ESM briefly discussed above and further analysed in the subsequent section.

Secondly, the Court repeated that, when the two institutions act under the ESM, they do not have the power to take decisions of their own and their activities are only binding on the ESM, in this way confirming its previous judgment in Pringle. ${ }^{38}$ A question arising, however, concerns who is responsible for checking whether the Commission and the ECB comply with the limits of their powers. It is one thing to say that, by law, an institution cannot act in a certain field, for a certain objective, in a certain way, or to a certain extent. Indeed, EU primary and secondary law is filled with examples of limitations to the powers of EU institutions to act, in a similar vein as the law prescribes the delimitation of EU competences. It is another thing altogether to scrutinise whether these institutions comply with the limits to their powers or not. Judicial review exists to fulfill this purpose. Otherwise it would have sufficed to say that because the law prescribes that institutions should act in a certain way, they certainly do so. Instead of imposing a strong level of judicial scrutiny on the two institutions, the ECJ in Mallis limited itself into reiterating the tasks of the two institutions as

\footnotetext{
${ }^{35}$ The MoU was drafted on the basis of Council Decision 2013/236/EU of 25 April 2013 addressed to Cyprus on specific measures to restore financial stability and sustainable growth [2013] OJ L141/32. It was endorsed by the Cyprus House of Representatives on 30 April 2013.

${ }^{36}$ For a more detailed discussion of the cases in the context of the Cyprus bail-in see Shaelou and Karatzia (n 34).

${ }^{37}$ Case T-327/13 Mallis and Malli v Commission and ECB [2014] ECLI:EU:T:2014:909, paras 41-3.

${ }^{38}$ Ibid paras 46-50; ECJ judgment in Joined Cases C-105/15 P to C-109/15 P Mallis, paras 52-3.
} 
expressed in the text of the ESMT. ${ }^{39}$ On this basis, it concluded that the Eurogroup statement was not the expression of the two institutions' decision-making powers.

Thirdly, the participation of the Commission and the ECB in the negotiation of the financial assistance packages and in signing a respective MoU, does not enable that MoU to be classified as an act that can be imputed to the two institutions. ${ }^{40}$ Since the ESMT is an international agreement signed outside the EU legal framework, the relevant MoUs are 'acts extraneous to the EU legal order ${ }^{41}$ and therefore their legality cannot be challenged under Article 263 TFEU. $^{42}$

The two final observations are definitely the most interesting. According to the Court, the fact that the ESM is outside the EU legal order does not prevent the Luxembourg Courts from examining a claim for damages under Article 340 TFEU against the two institutions for allegedly unlawful conduct during the adoption of a financial assistance programme. ${ }^{43}$ This ruling contrasts with the long-held position of the CJEU that a claim for judicial review of that same conduct is inadmissible under Article 263 TFEU. ${ }^{44}$

The case of Ledra constitutes a milestone in that it is the first occasion in which the ECJ reviewed the conduct of an EU institution -namely the Commission- under the ESM. Linked to this point, the ECJ also clarified for the first time that the EU Charter of Fundamental Rights was applicable to the EU institutions when acting outside the EU legal framework. The applicants in Ledra had essentially argued that the haircut on deposits was in breach of the right to property, contrary to Article 17(1) of the Charter and Article 1 of Protocol 1 of the European Convention on Human Rights (ECHR). On this account, they argued that the Commission had failed to fulfil its duty to ensure that the financial assistance programme was consistent with EU law.

After Ledra, we can speak in more certain terms about the duty of the Commission to ensure consistency between the MoUs signed by the ESM and EU law; a duty that derives from Pringle and Article 13(3) and (4) ESMT. According to the ECJ, the Commission

\footnotetext{
${ }^{39}$ Ibid paras 54-9.

${ }^{40}$ ECJ judgment in Joined Cases C-8/15 P to C-10/15 P Ledra, para 52.

${ }^{41}$ Opinion of AG Wahl in Joined Cases C-8/15 P to C-10/15 P Ledra Advertising Ltd v Commission and ECB [2016] ECLI:EU:C:2016:701, paras 52-3; Case C-370/12 Pringle, para 161; Case T-289/13 Ledra Advertising Ltd v Commission and ECB [2014] ECLI:EU:T:2014:981, para 47; ECJ judgment in Joined Cases C-8/15 P to C-10/15 P Ledra, para 53.

${ }^{42}$ ECJ judgment in Joined Cases C-8/15 P to C-10/15 P Ledra, paras 56-60.

${ }^{43}$ Ibid paras 55-61.

${ }^{44}$ See discussion accompanying notes $68-92$ in section 2.3 .
} 
'retains, within the framework of the ESM Treaty, its role of guardian of the Treaties as resulting from Article 17(1) TFEU. ${ }^{45}$ As a consequence, the Commission 'should refrain from signing a memorandum of understanding whose consistency with EU law it doubts. ${ }^{46}$ There are no further distinctions by the ECJ as to the character of this duty that would limit the obligations of the Commission: for example, there is no contrast in the case law between a positive and negative duty of the Commission which might have distinguished between a prohibition on the Commission to deliberately breach EU rules (negative duty) and an obligation incumbent on the Commission 'to avert any possible conflict or tension between the provisions of an act adopted by other entities and any EU rule which may be applicable to the situation. ${ }^{47}$ Instead, the ECJ in Ledra created a bridge between the interpretation of the institutions' powers in Pringle and the duties of the Commission under both EU law and the ESMT. Perhaps due to the fact that the applicants did not focus on the obligations of the ECB, the Court did not delve into the role of the ECB in the ESM.

\section{The missing parts: An analytical framework for the role of the Commission and ECB in the ESM}

The discussion has thus far focused on the key lessons drawn from Mallis and Ledra on the role of the Commission and the ECB in the ESM. We have thus far discussed "what we know' about the Commission and ECB, our main sources of knowledge being the CJEU's jurisprudence and the ESMT and By-Laws. The focus now shifts to the missing parts of the story or, indeed, 'what we do not know' about the role of the Commission and the ECB within the framework of the ESM.

\subsection{Who does what?}

It is axiomatic that any discussion on accountability begins with mapping the tasks conferred on the institution concerned, whose performance in carrying them out is then appraised by the accountability holder against a set of predefined standards. It is impossible to hold one to a set of standards, to judge whether one has met her responsibilities in light of these standards, and to impose sanctions (if that is an option) when the accountability holder does not even know what the institution has been precisely up to in a given context.

\footnotetext{
${ }^{45}$ ECJ judgment in Joined Cases C-8/15 P to C-10/15 P Ledra, para 59.

${ }^{46}$ Ibid.

${ }^{47}$ See, for this distinction, opinion of AG Wahl in Joined Cases C-8/15 P to C-10/15 P Ledra, para 85; Poulou (n 34); A Poulou 'Austerity and European Social Rights: How Can Courts Protect Europe's Lost Generation?' (2014) 15 German Law Journal 1145, 1159-60.
} 
There is little clarity about the respective roles of the Commission and the ECB within the framework of the ESM, over and above the ESMT provisions that were explicated above. We do not know what their precise tasks are, nor is their framework of cooperation crystal clear. What is more, we have very little information about their role and respective positions in the bailout negotiations, which makes it very difficult to assign responsibility to them for their actions in the ESM. This is all the more so with respect to the ECB's actions in the context of the ESM because the case law has not thus far dealt with the role of the ECB in the ESM. $^{48}$

It is understandable that one should be cautious to preserve a 'space to think' between and within these institutions, as the sensitivity of the bailout negotiations and their utmost significance for financial stability in the euro area and the Member State concerned so demand. Even EU primary law recognises that the extent of transparency obligations of an institution is sometimes dependent on the nature of the tasks undertaken by the said institution. ${ }^{49}$ However, this is not a normative reason for blurring the lines of responsibility or failing to provide at least some information on one's activities even ex post facto. For example, there is no mention of the ECB's activities in the ESM in the ECB's annual report for $2016 .{ }^{50}$ The report only mentions Mallis and Ledra under the heading 'ECB participation in judicial proceedings at the EU level, ${ }^{51}$ as well as the Greek Emergency Liquidity Assistance case. ${ }^{52}$ It is not readily explicable why the ECB's annual report makes no mention to the (perhaps limited) activities of the ECB in the ESM. ${ }^{53}$

\subsection{Which rules apply?}

We now turn to consider the rules that govern the activities of the Commission and the ECB in the ESM - a point of contention before the judgment in Ledra, especially as regards the scope of application of the EU Charter of Fundamental Rights. ${ }^{54}$ Some doubts, however, do

\footnotetext{
${ }^{48}$ See further Transparency International EU, 'Two Sides of the Same Coin? Independence and Accountability of the European Central Bank' (2017) <transparency.eu/wp-content/uploads/2017/03/TIEU_ECB_Report_DIGITAL.pdf> accessed 16 April 2017, 44-5.

${ }^{49}$ See art 15(3) TFEU which distinguishes the transparency obligations of the ECB depending on whether the institution concerned is exercising administrative or non-administrative tasks.

50 European Central Bank, Annual Report 2016, available at: <www.ecb.europa.eu/pub/annual/html/index.en.html> accessed 4 May 2017.

${ }^{51}$ Ibid 86-7.

52 Ibid 87; Case T-368/15 Alcimos Consulting SMPC v European Central Bank [2016] EU:T:2016:438.

${ }^{53}$ See European Central Bank, 'The European Stability Mechanism' (July 2011) ECB Monthly Bulletin 77.

${ }^{54}$ See generally C Barnard, 'The Charter, the Court - and the Crisis' (2013) University of Cambridge Faculty of Law Legal Studies Research Paper 18/2013, 13; A Hinarejos, 'Bailouts, Borrowed Institutions, and Judicial Review: Ledra Advertising' (EU Law Analysis Blog, 25 September 2016)
} 
remain as to whether all EU law should apply to the activities of the EU institutions in the ESM. We argue that all EU law should in principle apply to the activities of the Commission and the ECB in the ESM (section 3.2.1). Though the principle ought to be, in our opinion, very clear, the precise obligations incumbent on the Commission and-even more so- on the ECB evade neat classification (section 3.2.2).

\subsubsection{All EU law applies, in principle, to the activities of the $E U$ institutions in the ESM}

As regards the obligations incumbent on the EU institutions in the context of the ESM, in Ledra the challenge was indeed based on the EU Charter of Fundamental Rights and more specifically on the right to property (Article 17(1) of the Charter). However, the Court is making a much broader point about the applicability of EU law to the actions of the Commission and the ECB in the context of the ESM. ${ }^{55}$ Should all EU law govern the actions of the EU institutions within the framework of the ESM? In other words, are the Commission and the ECB bound by the full scope of EU law when acting within the formal confines of the ESM Treaty?

First of all, it is clear from the Court's reasoning in Ledra that the EU institutions are not just bound by the Charter when acting in the ESM. The Commission's obligation to ensure that the MoUs concluded between the ESM and recipient Member States are consistent with the fundamental rights guaranteed by the Charter was said by the Court to derive from Article 17(1) TEU and Article 13(3)-(4) ESMT. ${ }^{56}$ Leaving the ESMT provision aside for the moment, it is clear that the Court's reasoning is premised on the assumption that Article 17(1) TEU binds the European Commission also when acting outside the formal confines of the EU Treaties. ${ }^{57}$

In light of the above, a new conclusion arises with regard to the role of the Commission and the ECB. We argue that all primary and secondary EU law should in principle govern the activities of the Commission and the ECB in the ESM. We believe this point was made rather clear in Ledra. Furthermore, we see no doctrinal or normative reason

<eulawanalysis.blogspot.nl/2016/09/bailouts-borrowed-institutions-and.html> accessed 26 September 2016; C Kilpatrick, 'Are the Bailouts Immune to EU Social Challenge Because They Are Not EU Law?' (2014) 10 EuConst 393, 406; S Peers, 'Towards a New Form of EU Law? The Use of EU Institutions outside the EU Legal Framework’ (2013) 9 EuConst 37, 51-3.

${ }^{55}$ See notably ECJ judgment in Joined Cases C-8/15 P to C-10/15 P Ledra, paras 58-9, where the Court speaks of 'consistency with EU law'.

${ }^{56}$ Ibid para 67.

${ }^{57}$ See also ibid para 59. 
why specifically the EU Charter of Fundamental Rights should apply to the activities of the EU institutions involved in the ESM, to the exclusion of other primary or indeed secondary EU law. In this regard, we have already seen an example from EU secondary law governing the activities of the EU institutions in this context. EU rules on access to documents may indeed be drawn upon to obtain key information from the EU institutions, as explained above (section 2.1). The Eurogroup President seems to be in agreement with this proposition, as shown from his exchange of letters with the European Ombudsman on transparency in the workings of the Eurogroup and the Eurogroup Working Group. ${ }^{58}$ This reinforces the argument regarding the application of EU law to the institutions.

It is noted, however, that there might be cases where the relevant EU provisions do not 'fit' into this context, given their wording, scope, structure and objectives, and therefore it cannot altogether be excluded that some EU provisions might not be applicable in concreto. Having said that, it is difficult to determine in the abstract which these provisions might be, as this would require an ad hoc examination in the light of the particular circumstances of each case.

\subsubsection{The obligations incumbent on the ECB in the ESM}

We have seen above that the ECJ focused in Ledra on the legal obligations incumbent on the Commission when signing the MoU on behalf of the ESM. There is much less by way of legal material (case law or academic literature) on the obligations incumbent on the ECB in the ESM. In fact, there is an interesting symmetry between the tasks and duties conferred on the ECB in the ESM. There is little clarity on the ECB's role in the ESM; and equally little clarity on the ECB's duties when acting in the ESM.

Arguably, it was easier because of the Court's reasoning in the earlier case of Pringle to make the argument in Ledra that the Commission ought to ensure that the MoU is

\footnotetext{
58 European Ombudsman, 'Recent Initiative to Improve Eurogroup Transparency' (14 March 2016) <www.ombudsman.europa.eu/resources/otherdocument.faces/en/65359/html.bookmark> accessed 7 March 2017; Council of the European Union, 'Reply from the Eurogroup President to the European Ombudsman's Letter on Eurogroup Transparency' (31 May 2016) <www.consilium.europa.eu/en/press/pressreleases/2016/05/31-peg-letter-ombudsman/> accessed 7 April 2017; European Ombudsman, 'Follow-up Response from the European Ombudsman to the Reply of President Dijsselbloem to her Letter Concerning Eurogroup $\quad$ Transparency' $\quad$ (30 August $\quad$ 2016) <www.ombudsman.europa.eu/resources/otherdocument.faces/en/70708/html.bookmark> accessed 7 March 2017; Council of the European Union, 'Reply from the Eurogroup President to the European Ombudsman's Letter on Eurogroup Transparency' (1 December 2016) <www.consilium.europa.eu/en/press/pressreleases/2016/12/01-eurogroup-peg-letter-ombudsman/> accessed 7 April 2017.
} 
compatible with the Charter. ${ }^{59}$ In Pringle, the Court noted that 'it [was] stated in Article 17(1) TEU that the Commission "shall promote the general interest of the Union" and "shall oversee the application of Union law". ${ }^{60}$ The Court further added that "the tasks allocated to the Commission by the ESM Treaty enable[d] it, as provided in Article 13(3) and (4) of that Treaty, to ensure that the memoranda of understanding concluded by the ESM are consistent with European Union law'. ${ }^{61}$ Pringle was, however, very light on detail with respect to the role of the ECB in the ESM. ${ }^{62}$ The only obiter dictum that is pertinent for present purposes was that ' $[\mathrm{b}] \mathrm{y}$ virtue of its duties within the ESM Treaty, the ECB supports the general economic policies in the Union, in accordance with Article 282(2) TFEU' ${ }^{63}$ It is only then logical and coherent with the structure and objectives of the EU Treaties to infer that the ECB may not endanger price stability when acting in the ESM, as this is its primary objective and it may only support the general economic policies in the Union '[w]ithout prejudice to that objective' ${ }^{64}$ Hence we can safely argue that the ECB has a duty to avoid endangering price stability when acting under the ESM, in line with its EU Treaties mandate (Article 127 TFEU).

Nevertheless, the ECB's Treaty obligations when acting in the ESM do not stop there. It is further provided in Article 127(1) TFEU that ' $[\mathrm{t}]$ he ESCB [which is governed by the decision-making bodies of the ECB] shall act in accordance with the principle of an open market economy with free competition, favouring an efficient allocation of resources, and in compliance with the principles set out in Article 119'. These include 'stable prices, sound public finances and monetary conditions and a sustainable balance of payments' ${ }^{65}$ Consequently, the ECB should in principle object to a bailout programme whose fiscal targets, for example, are either not rigid enough or unattainable. Moreover, the very robust Treaty provisions on the ECB's independence are also applicable in the ESM context and should therefore be respected by the EU and national institutions involved in the bailout negotiations. ${ }^{66}$ The ECB cannot be 'forced' for example to use its monetary policy tools in a certain manner as part of a bailout agreement.

Unfortunately, the latest case law on the ECB does not advance the debate any

\footnotetext{
${ }^{59}$ Case C-370/12 Pringle, paras 163-4.

${ }^{60}$ Ibid para 163.

${ }^{61}$ Ibid para 164.

${ }^{62}$ Ibid para 165.

${ }^{63}$ Ibid para 165.

${ }^{64}$ Art 282(2) TFEU; see also art 127(1) TFEU.

${ }^{65}$ Art 119(3) TFEU.

${ }^{66}$ Arts 130-31 TFEU.
} 
further. The Nausicaa case concerns the Greek debt cut, and legal argument revolves around general principles of EU law. ${ }^{67}$ The Court has not yet had the opportunity to elaborate further on the obligations incumbent on the Commission and - even more so - on the ECB in the context of the ESM. Be that as it may, this has important consequences for holding these two institutions accountable for their activities in the ESM, as explained in the next section.

\subsection{Who can ultimately be held responsible and how?}

The discussion thus far has focused on the rules applicable to the activities of the Commission and the ECB in the ESM. How are these rules enforced and who monitors the activities of the EU institutions in the ESM? There is an elephant in the room, as accountability can be very difficult to secure in this context. The key message from the relevant literature is that the intergovernmentalist, non-EU legal nature of the ESM compounds the difficulties in terms of holding the EU institutions and ESM bodies accountable to political and legal fora. ${ }^{68}$

As regards the role of parliaments, the ESMT does not even mention the European Parliament. In practice, the ESM's Managing Director, Klaus Regling, participates in hearings in the European Parliament whenever he is asked to do so. ${ }^{69}$ As regards national parliaments, the ESMT merely requires that the annual report from the ESM's Board of Auditors be transmitted to them. ${ }^{70}$ Nevertheless, the parliaments of the Eurozone Member States have a role in holding their finance ministers and other officials separately to account for their actions in the ESM. It is in this sense that accountability is 'decentralised': the Board of Governors or Directors is not accountable to the European (or a national) Parliament as a body, and therefore national parliaments may only hold their own government officials accountable for their actions in the ESM, in accordance with the national constitutional requirements. $^{71}$

Though the ESMT grants the power to the CJEU to adjudicate on disputes between an ESM member and the ESM, or between ESM members, on the interpretation and application

${ }^{67}$ Case T-749/15 Nausicaa Anadyomène SAS and Banque d'escompte v European Central Bank [2017] ECLI:EU:T:2017:21.

${ }^{68}$ See B De Witte, 'Using International Law in the Euro Crisis: Causes and Consequences' (June 2013) Arena Working Paper No 4 <www.sv.uio.no/arena/english/research/publications/arena-working-papers/2013/wp413.pdf> accessed 20 March 2017, 18-23; A Hinarejos, The Euro Area Crisis in Constitutional Perspective (OUP 2015) ch 6; Tuori and Tuori (n 12) 157-62.

${ }^{69}$ Transparency International EU (n 21) 7.

${ }^{70}$ Art 30(5) ESMT.

${ }^{71}$ See Transparency International EU (n 21) 7-8. 
of the ESMT and By-Laws, ${ }^{72}$ it is only fair to argue that in all likelihood there will not be many such disputes submitted to the CJEU, if any at all, due to the political sensitivities involved. Moreover, natural and legal persons do not have standing to bring a case before the CJEU challenging the legality of ESM acts as the ESMT now stands. This point should be kept in mind pending the ESMT's incorporation in the EU Treaties, which will be discussed in section 4.

As regards judicial protection in the peculiar context of EMU, there are a number of issues which have not yet been clarified in the relevant case law. We have already seen in the lessons drawn from Mallis and Ledra that the MoU and the acts of the ESM bodies are nonEU legal measures and therefore cannot be directly challenged before the CJEU. Statements by the Eurogroup are not subject to review by the CJEU either, as the Eurogroup does not formally have legally binding powers. We assume by the same token that Euro Summit statements could not be challenged before the CJEU either.

What is then left in terms of direct or indirect actions for crisis-hit litigants from ESM countries wishing to put their substantive case before the CJEU? An Article 263 TFEU action for annulment would almost never be available to non-privileged applicants (natural or legal persons). Even if the latter could locate a formally binding EU law measure adopted by -most likely- the Council pursuant to the Excessive Deficit Procedure ${ }^{73}$ or 'two-pack' legislation, ${ }^{74}$ they would almost always be unable to meet the requirements of direct and individual concern. ${ }^{75}$ This is evidenced in the Greek ADEDY cases. $^{76}$

Alternatively, private persons might be able to use the Article 267 TFEU preliminary reference route. However, they would again be faced with substantial difficulties, which are not specific to the EMU context. First, 'the applicant has no right to decide whether a reference is made, which measures are referred for review or what grounds of invalidity are raised and thus no right of access to the Court of Justice'. ${ }^{77}$ Secondly, there might be no

\footnotetext{
72 Art 37 ESMT.

${ }^{73}$ Art 126 TFEU.

${ }^{74}$ Art 7 of Regulation (EU) 472/2013 of the European Parliament and of the Council of 21 May 2013 on the strengthening of economic and budgetary surveillance of Member States in the euro area experiencing or threatened with serious difficulties with respect to their financial stability [2013] OJ L140/1.

${ }^{75}$ Art 263(4) TFEU.

${ }^{76}$ Case T-541/10 Anotati Dioikisi Enoseon Dimosion Ypallilon (ADEDY), Spyridon Papaspyros and Ilias Iliopoulos v Council of the European Union [2012] ECLI:EU:T:2012:626; Case T-215/11 Anotati Dioikisi Enoseon Dimosion Ypallilon (ADEDY), Spyridon Papaspyros and Ilias Iliopoulos v Council of the European Union [2012] ECLI:EU:T:2012:627 (concerning Council decisions adopted pursuant to arts 126(9) and 136 TFEU within the framework of the excessive deficit procedure).

${ }^{77}$ Opinion of AG Jacobs in Case C-50/00 Unión de Pequeños Agricultores $v$ Council of the European Union
} 
challengeable implementing measures or - more plausibly- the applicant might have to break the law in order to be able to challenge ensuing sanctions. ${ }^{78}$ Thirdly, it is well known that 'indirect challenges (...) present a number of procedural disadvantages in comparison to direct challenges (...) as regards for example the participation of the institution(s) which adopted the measure, the delays and costs involved, the award of interim measures or the possibility of third party intervention'. ${ }^{79}$ Litigants would most likely have to fight their way through more than one national court, as only courts or tribunals against whose decisions there is no judicial remedy under national law are obliged to make a reference to the CJEU for a preliminary ruling. ${ }^{80}$

Some difficulties linked to making an Article 267 TFEU challenge against the actions of the EU institutions are, however, specific to the peculiar context of EMU. It should not escape our attention that the challenges thus far made to bailout terms through the Article 267 TFEU route have all been declared inadmissible. This is evidenced by the Romanian ${ }^{81}$ and Portuguese MoU cases, ${ }^{82}$ which at the very least attest to the difficulties involved in establishing a link between the contested bailout terms and EU law measures.

The only viable option available to non-privileged applicants would then be an Article 340 TFEU action for damages, with all its difficulties and uncertainties which are yet to be clarified in the relevant case law. For one, the requirement of a sufficiently serious breach of a rule of EU law intended to confer rights on individuals would almost never be met by litigants in this context, as the EU institutions concerned undertake complex economic assessments and are, generally speaking, granted a wide margin of appreciation. We have seen in Ledra that the Court of Justice ruled that there was no disproportionate interference

[2002] ECR I-6677, para 102. For a discussion on judicial protection in the EU as a vital component of the EU rule of law, see T Konstadinides, The Rule of Law in the European Union: The Internal Dimension (Hart Publishing 2017).

78 Ibid para 102.

${ }^{79}$ Ibid para 102; see further Kilpatrick (n 54).

${ }^{80}$ Art 267(2)-(3) TFEU.

${ }^{81}$ Case C-434/11 Corpul Național al Polițiștilor v Ministerul Administrației și Internelor (MAI), Inspectoratul General al Poliției Române (IGPR), Inspectoratul de Poliție al Județului Alba (IPJ) [2012] OJ C73/13; Case C462/11 Victor Cozman v Teatrul Municipal Târgoviște [2012] OJ C73/13; Case C-134/12 Ministerul Administraţiei şi Internelor (MAI), Inspectoratul General al Politiei Române (IGPR) and Inspectoratul de Poliţie al Judeţului Tulcea (IPJ) v Corpul Naţional al Poliţiştilor - Biroul Executiv Central [2012] OJ C303/9; Case C-369/12 Corpul Național al Polițiștilor - Biroul Executiv Central, reprezentant al reclamanților Chițea Constantin și alții v Ministerul Administrației și Internelor, Inspectoratul General al Poliției Române, Inspectoratul de Poliție al Județului Braşov [2013] OJ C108/12.

82 Case C-128/12 Sindicato dos Bancários do Norte, Sindicato dos Bancários do Centro, Sindicato dos Bancários do Sul e Ilhas, Luís Miguel Rodrigues Teixeira de Melo v BPN - Banco Português de Negócios SA [2013] OJ C129/3; Case C-264/12 Sindicato Nacional dos Profissionais de Seguros e Afins v Fidelidade Mundial - Companhia de Seguros SA [2014] OJ C315/26; Case C-665/13 Sindicato Nacional dos Profissionais de Seguros e Afins v Via Directa - Companhia de Seguros SA [2014] OJ C16/11. 
with the right to property. It could be argued that the Cypriot cases were 'difficult cases', as the application of the 'bail-in' tool to the Cypriot banks was deemed to be absolutely necessary in order to safeguard financial stability. Moreover, there is always an argument to be made in 'bail-in' cases that the depositors do not incur greater losses than they would have incurred had the banks collapsed ('no creditor worse off' principle). ${ }^{83}$

However, as shown in the latest case law, claims for damages resulting from pension cuts -a relatively 'easier' case, given the existence of ECtHR case law ${ }^{84}$ that the CJEU could have drawn upon- ${ }^{85}$ were equally unsuccessful. In the Sotiropoulou case, the impugned cuts were mandated by a Council decision which was adopted on the basis of Articles 126(9) and 136 TFEU. $^{86}$ The General Court found no violation of Articles 1 (dignity), 25 (the rights of the elderly) and 34 (social security and social assistance) of the EU Charter of Fundamental Rights. The Council had not manifestly and gravely disregarded the limits of its discretion, the emphasis being, unsurprisingly, on its wide margin of appreciation. ${ }^{87}$ What is more, the Sotiropoulou case goes to show that litigants might sometimes not even be able to locate a rule of law intended to confer rights on them for the purposes of establishing the noncontractual liability of the EU institutions for damages caused to them. In the case of Sotiropoulou, the General Court held that the rules on EU competence (Articles 4 and 5

\footnotetext{
${ }^{83}$ Art 34(1)(g) of Directive 2014/59/EU of the European Parliament and of the Council of 15 May 2014 establishing a framework for the recovery and resolution of credit institutions and investment firms and amending Council Directive 82/891/EEC, and Directives 2001/24/EC, 2002/47/EC, 2004/25/EC, 2005/56/EC, 2007/36/EC, 2011/35/EU, 2012/30/EU and 2013/36/EU, and Regulations (EU) No 1093/2010 and (EU) No 648/2012, of the European Parliament and of the Council [2014] OJ L173/190; Art 15(1)(g) of Regulation (EU) $806 / 2014$ of the European Parliament and of the Council of 15 July 2014 establishing uniform rules and a uniform procedure for the resolution of credit institutions and certain investment firms in the framework of a Single Resolution Mechanism and a Single Resolution Fund and amending Regulation (EU) No 1093/2010, [2014] OJ L225/1.

${ }^{84}$ See, e.g., Koufaki and ADEDY v Greece App nos 57665/12 and 57657/12 (ECtHR, 7 May 2013) (concerning wage and pension cuts in the context of the first Greek MoU); Mamatas and Others $v$ Greece App nos 63066/14, 64297/14 and 66106/14 (ECtHR, 21 July 2016) (concerning the 'haircut' on Greek government bonds); DA CONCEIÇÃO MATEUS and SANTOS JANUÁRIO v Portugal App nos 62235/12 and 57525/12 (ECtHR, 8 October 2013) (concerning a reduction in holiday and Christmas subsidies in the context of the Portuguese MoU); Frimu and Others v Romania App nos 45312/11, 45581/11, 45583/11, 45587/11 and 45588/11 (ECtHR, 13 November 2012) (concerning divergent court rulings on pension reduction; no violation of arts 6 and 14); Mihăieş and Senteş v Romania App nos 44232/11 and 44605/11 (ECtHR, 6 December 2011) (concerning a temporary salary reduction; no violation of art 1 of the First Added Protocol to the ECHR); Maggio and Others $v$ Italy App nos 46286/09, 52851/08, 53727/08, 54486/08 and 56001/08 (ECtHR, 31 May 2011) (concerning the method of calculation of old-age pensions); Stefanetti and Others $v$ Italy App nos 21838/10, 21849/10, 21852/10, 21855/10, 21860/10, 21863/10, 21869/10 and 21870/10 (ECtHR, 15 April 2014) (the circumstances of the case are analogous to those described in Maggio and Others $v$ Italy, but the applicants in Stefanetti and Others $v$ Italy had suffered a $67 \%$ loss of their respective pensions).

${ }_{85}$ See art 52(3) of the EU Charter of Fundamental Rights.

${ }^{86}$ Case T-531/14 Sotiropoulou and Others $v$ Council of the European Union [2017] ECLI:EU:T:2017:297.

${ }^{87}$ Ibid paras 75-93.
} 
TFEU) were not intended to confer rights on the applicants. ${ }^{88}$ Had an Article 263 TFEU challenge been available, these grounds could have been invoked to annul -if found validthe measure.

Establishing a causal link between the conduct of the EU institution concerned and the damage caused to the individual might also prove tricky for litigants in this area. This is all the more so in the case of 'prior actions', that is measures that were adopted by the national authorities prior to the conclusion of the MoU. In the case of Cyprus, it will be recalled that the General Court ruled in Ledra that the applicant had not established with the necessary certainty that the damage it claimed to have suffered from the 'bail-in' of its deposits was actually caused by the inaction alleged against the Commission. ${ }^{89}$ This point was not addressed by the ECJ on appeal, as the claim failed on the first requirement for noncontractual liability (that is, showing a sufficiently serious breach of EU law). As such, we do not know if 'prior actions' are indeed shielded from review by the EU courts in this sense, or whether perhaps the ECJ might hold a different opinion on the issue. It would seem that the ECJ is implicitly disagreeing with the General Court on this point, but the point was not per se addressed by the Court. $^{90}$

Furthermore, it is not clear what it would take for the ECB to be held liable for damages caused to private persons through its actions within the framework of the ESM. ${ }^{91}$ It is difficult to think of a rule of law intended to conferred rights on individuals that could be breached by the ECB in a sufficiently serious manner when carrying out its tasks in the ESM. This is all the more so since it is only the Commission that is signing the MoU on behalf of the ESM. The complex analyses undertaken by the ECB in the context of the ESM are not of the type that could easily give rise to a claim for damages for breach of EU law. ${ }^{92}$

\section{Forward-looking assessment: Incorporating the ESM governance framework into the EU legal framework}

Looking forward, the ESM could perhaps be incorporated into EU law, as was suggested in

\footnotetext{
${ }^{88}$ Ibid paras 67-73.

${ }^{89}$ Case T-289/13 Ledra, para 54.

${ }^{90}$ See further Shaelou and Karatzia (n 34).

91 Arts 268 and 340(3) TFEU.

${ }^{92}$ For the approach of the CJEU in cases involving discretion of EU institutions, see P Craig, EU Administrative Law (2nd edn, OUP, Oxford 2012) ch 15.
} 
the Five Presidents' Report in order to enhance accountability in the area of EMU ${ }^{93}$ Until then, the ESM will remain partly outside the scope of application of Treaty provisions and EU secondary law, as well as the EU Charter of Fundamental Rights. ${ }^{94}$ This is because the acts adopted by ESM bodies are non-EU law measures. What is more, the role of parliaments, courts and various EU bodies and agencies will remain limited, as explained above. ${ }^{95}$

The Five Presidents' Report is, however, vague as to how the ESM's governance framework should be integrated within the EU Treaties. Should the ESM become an EU institution within the meaning of Article 13 TEU? Should it perhaps take the form of an EU agency or body? What should its institutional, accountability and transparency arrangements look like? Should perhaps the influence of larger Member States be mitigated? And how would the ESM interrelate with the existing EU bodies (informal or otherwise) such as the Eurogroup and the Eurogroup Working Group whose membership is identical to the ESM bodies?

We believe that the ESM should become an EU institution (rather than an agency) so as to avoid the complex, byzantine governance structures that pertain to the area of Banking Union. We are mostly speaking of the Single Resolution Mechanism, as it is the Single Resolution Board that took the form of an EU agency and its decision-making processes are, by reason of EU constitutional constraints, incredibly complex. ${ }^{96}$ One benefit of incorporating the ESM within the EU legal order would be that the transparency and accountability of the ESM's operations should be enhanced. Its integration into the fabric of EU law would already go a long way to addressing the concerns identified in this paper, as the ESM would be able to benefit from the services of and synergies with the EU institutions, bodies, offices and agencies (the European Parliament, Ombudsman, Fundamental Rights Agency, Court of Auditors, Data Protection Supervisor, and the European Anti-Fraud Office $(\mathrm{OLAF})) .{ }^{97}$ This is predicated on the assumption that the powers of the EU institutions,

\footnotetext{
${ }^{93}$ Five Presidents' Report (n 3) 18. A discussion of whether the incorporation of the ESM in EU law is likely to be materialised and of the political and pragmatic difficulties accompanying this scenario falls outside the scope of this article.

94 Tuori and Tuori (n 12) 218; Transparency International EU (n 21) 7.

95 Transparency International EU (n 21) 7.

${ }^{96}$ See generally D Busch, 'Governance of the Single Resolution Mechanism' in D Busch and G Ferrarini (eds), European Banking Union (OUP, Oxford 2015) ch 9; E Ferran, 'European Banking Union: Imperfect, But It Can Work' in D Busch and G Ferrarini (eds), European Banking Union (OUP, Oxford 2015) ch 3; M Markakis, 'Political and Legal Accountability in the European Banking Union: A First Assessment' in M Szabó and others (eds), Hungarian Yearbook of International and European Law 2016 (Eleven Publishing, The Hague 2017) ch 32.

${ }^{97}$ Transparency International EU (n 21) 7.
} 
bodies and agencies would not be restricted in the case of ESM. Similarly, if the aim is to make a real change in the EMU accountability arrangements, the powers of the CJEU should not be restricted in this area in an AFSJ fashion. All the acts of the ESM should in principle be subject to full review by the CJEU upon the ESM's incorporation into the EU Treaties.

In any event, the implementation of this proposal would not solve all problems identified with respect to judicial review in this area of law. The rules on standing for Article 263 TFEU challenges would remain restricted for non-privileged applicants. The procedural difficulties identified above with respect to Article 267 TFEU challenges would continue to exist. Meeting the requirements for non-contractual liability of the EU institutions would remain a tall order. The above-mentioned limitations on transparency and access to documents would probably still bite, by way of explicit exceptions built into the relevant EU instruments, thereby further compounding the difficulties for litigants wishing to bring a case before the EU courts. Furthermore, we do acknowledge that the EU courts would most likely be deferential to the ESM bodies in future cases brought before them.

\section{Conclusion}

This article has considered the role of the Commission and the ECB in the ESM. It examined the legislative framework applying to the ESM, including soft law issued by the ESM itself (e.g. the ESM By-Laws) and recent litigation challenging the actions of the two institutions in the Mechanism. Taking stock of the lessons learned from recent case law, the article has put forward an analytical framework that aims to identify the law applicable to the two institutions when acting in the ESM, including their respective obligations. Certain features of this contribution are particularly pertinent in the context of the debate on this topic which, surprisingly, has remained rather unexplored after the initial stages of the ESM's life.

In particular, the analysis in this contribution has indicated that the legal framework pertaining to the activities of the EU institutions in the ESM is unclear. We have seen that the CJEU has given the green light to the participation of the Commission and the ECB in the ESM in Pringle and has further elaborated in Ledra on the responsibilities of the Commission when acting in the ESM. Yet the lack of precise information about the institutions' activities or respective positions in the meetings and the negotiations taking place within the ESM do not allow us to develop a complete understanding of the specifics of their role. This is all the more so with respect to the involvement of the ECB in the negotiations for financial 
assistance packages, a matter which remains entirely untouched by the CJEU to date. The ESM Transparency Initiative is a welcome development in the quest to unravel the involvement of the two institutions in the ESM.

Beyond the issues with transparency, the article has sought to identify which law applies to the activities of the EU institutions in the ESM. In this respect, we have argued that it is not just the EU Charter that should govern the activities of the Commission (and the ECB) in the ESM. Instead, the whole body of EU law (including primary and secondary EU law) should in principle govern the activities of the two institutions, unless one can point to a reason specific to a certain EU law act or Treaty provision that would render them inapplicable to the activities of the EU institutions in the ESM. Admittedly, although the discussion in this article has identified some of the concrete duties of the EU institutions when acting in the ESM, it is difficult to specify in the abstract the entire range of the institutions' duties. Nevertheless, the principle that the entire body of EU law applies to the situation at hand ought to be very clear. It is firmly based on the Court's reasoning in Ledra, and reinforced by other documents, such as the ESM By-Laws, which stipulate that EU institutions are bound by EU law on disclosure of their documents even when acting for the benefit of the ESM.

Finally, it was seen that, despite the application of the full scope of EU law, it can be difficult to hold the EU institutions and ESM bodies politically and legally accountable for their activities in the ESM. In this connection, it was argued that the incorporation of the ESM into the EU law framework would go a long way in addressing the difficulties involved in holding the ESM bodies and EU institutions accountable for their actions. It would especially enhance transparency and give rise to synergies with various EU institutions, bodies and agencies, such as the European Parliament, the Court of Auditors, and the European Ombudsman.

The identified potential for enhancing the accountability of the ESM would depend, however, on the precise legal and institutional arrangements pertaining to the ESM upon its incorporation into the EU law framework. To maximise the benefits in terms of accountability and transparency and minimise the complexity of the ensuing institutional arrangements, the ESM should take the form of an EU institution within the meaning of Article 13 TEU. This option would -in principle- bring the acts and omissions of the ESM under the full review of the CJEU. Whether the CJEU will defer to the assessment made by 
the ESM in a given case is another matter. Meanwhile, we will have to wait and see what will happen when the integration of the ESM within the EU legal framework becomes a priority as part of the plan to 'complete the EMU Architecture'. 98

${ }^{98}$ Five Presidents' Report (n 3) 21. 